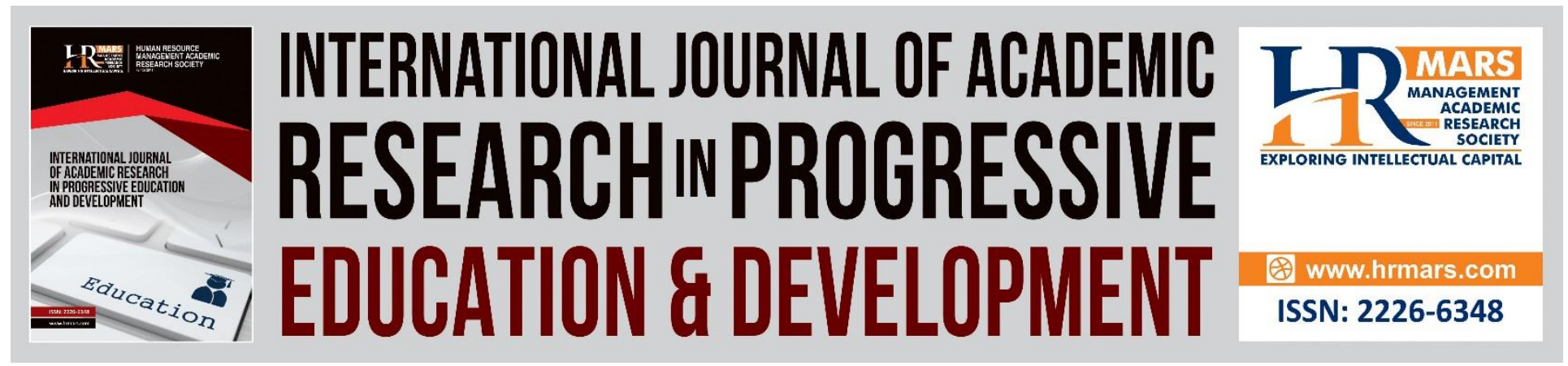

\title{
Online Distance Learning Perception and Readiness During Covid-19 Outbreak: A Research Review
}

\author{
Masri bin Abdul Lasi
}

To Link this Article: http://dx.doi.org/10.6007/IJARPED/v10-i1/8593

DOI:10.6007/IJARPED/v10-i1/8593

Received: 30 December 2020, Revised: 25 January 2021, Accepted: 10 February 2021

Published Online: 28 February 2021

In-Text Citation: (Lasi, 2021)

To Cite this Article: Lasi, M. bin A. (2021). Online Distance Learning Perception and Readiness During Covid-19 Outbreak: A Research Review. International Journal of Academic Research in Progressive Education and Development, 10(1), 63-73.

Copyright: (C) 2021 The Author(s)

Published by Human Resource Management Academic Research Society (www.hrmars.com)

This article is published under the Creative Commons Attribution (CC BY 4.0) license. Anyone may reproduce, distribute, translate and create derivative works of this article (for both commercial and non-commercial purposes), subject to full attribution to the original publication and authors. The full terms of this license may be seen at: $\underline{\text { http://creativecommons.org/licences/by/4.0/legalcode }}$

Vol. 10(1) 2021, Pg. 63 - 73

http://hrmars.com/index.php/pages/detail/IJARPED

JOURNAL HOMEPAGE

Full Terms \& Conditions of access and use can be found at http://hrmars.com/index.php/pages/detail/publication-ethics 


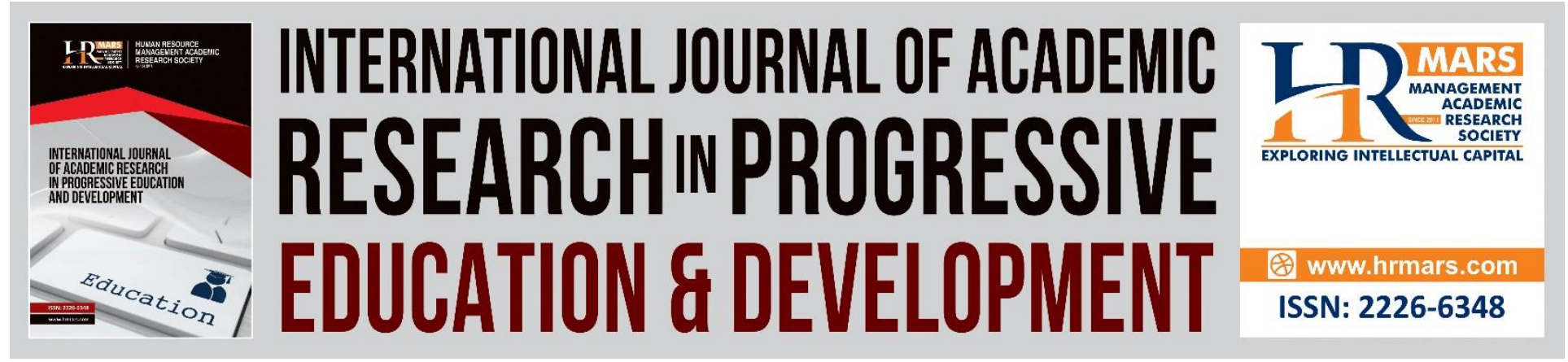

\title{
Online Distance Learning Perception and Readiness During Covid-19 Outbreak: A Research Review
}

\author{
Masri bin Abdul Lasi \\ Faculty of Business, City Graduate School, City University of Malaysia, Kuala Lumpur.
}

\begin{abstract}
The purpose of this study is to understand the perception and readiness on online distance learning. The study aims to add to the growing body of knowledge that has looked at many different variables that may affect educator and student performance by using a qualitative analysis approach research review, this study reviewed 26 published papers and research studies on the online learning, this study focusing on how theories, practices and assessments online to the current environment. The propose of this study is to provide suggestion for online distance learning. Based on this review, author focuses on the online distance learning, perceptions online distance learning at tertiary level educator and readiness to online distance learning, Because of challenges are interrelated, based on the findings, the researcher propose a conceptual framework of emerging issues for e-learning in Malaysia. The framework is useful to guide both practice and research. The researchers would like to recommend for future research to investigate the comparison between students' and lecturer's readiness to use Online Distance Learning (ODL) by using quantitative approach where more respondents can participate in the study.

Keywords: Online Distance Learning, Learner Perceptions, Readiness, Educator, Higher Learning Institution.
\end{abstract}

\section{Introduction}

For the last few decades, the method to teaching and learning in higher learning institutions has been steadily evolving. In order to keep up with emerging trends, the advent of technology offers essential reasons for the education sector to make changes Tanis. C.J (2020). Such changes include the syllabus and implementation format being changed. A few years ago, 21st Century Learning was implemented as a roadmap for educators to combine their lessons with technology. Many learning institutions have since moved from traditional education to online teaching. In Asia, India leads in online learning and China, which has been referred to as "home to almost 70 online colleges," is closely behind. In the United Kingdom and Australia, since 2012, online education has increased by at least $20 \%$ and the number continues to grow every year, indicating that the education environment is shifting (Edudemic, 2012). E-learning is an approach to 
learning using the internet and technology in Malaysia, which began in 2000 to establish elearning (Maznah, 2004).

Recently, the world has been struck with a pandemic Covid-19 that gave impact to all sectors including education. Suddenly the online education has become widely known among educators and forced them to use it due to the closure of schools by most governments around the world. The use of technology has become a priority to the educators around the world leading to the educational opportunity for those who can afford it. According to the data by UNESCO on its website, the closures are impacting about $60 \%$ of world's student population and bring difficulties especially to the students in non-developed countries and low income families that couldn't afford to use the technology (UNESCO, 2020). Education is a need in this world today, so does the technology.

Therefore, in 2015, the government released the Malaysia Education Blueprint 2015-2025 to improve the education sector in accordance with IR 4.0.0. (MoE, 2015). For the last decade, many efforts have been put by the universities to develop the online learning system. Future education or Education 4.0 which includes online learning must be able to produce highly creative graduates with the ability to think critically irrespective of disciplines (Abdul Haseeb, 2018). This will become the challenges that the educators need to face when dealing with online. Future education or Education 4.0, like online learning, must be capable of producing exceptionally innovative learners with the potential to think creatively independently of disciplines (Abdul Haseeb, 2018).

Past researches have reported the positive impact of e-learning used in education, e-learning helps to enhance user's knowledge and performance, skills and increase productive capabilities of the learners in a global situation. E-learning also reacted as personalize learning system which enable learners in accessing information from internal and external and points of access for constituent groups. Malaysia is no exception to experience this beneficial platform for their students particularly among distance learners. City Education Group, City University Malaysia has started using e-learning in distance learning program and played a large role in student learning. CEO in City $-U$ has carried out the video conferencing, forum, lecturer notes and also eportal in assisting their students. Although the technology was invoked in improving the distance learning program, learning was grounded in structured course module.

\section{Literature Review}

Traditional face-to-face learning has been replaced by online learning for a period of less than one month to ensure continuity of education. This paper aims to explore the preparation and understanding of online learning among university students and educators who have been thrown into the deep end. The current study focuses to examine the readiness and perception of students on online distance learning. Due to the Movement Control Order by the Malaysian Government.

E-learning is an approach to learning using the internet and technology in Malaysia, which began in 2000 to establish e-learning. Recently, the world has been struck with a pandemic Covid-19 
that gave impact to all sectors including education. In 2015, the government released the Malaysia Education Blueprint 2015-2025 to turn the education industry to comply with IR 4.0.0. Future education must be able to produce extremely innovative learners, independent of disciplines, with the capacity to think objectively.

This will become the challenges that the educators need to face when dealing with online education. The use of technology has become a priority to the educators around the world leading to the educational opportunity for those who can afford to use it. The advancement of technology not only affects the human lifestyles, but it also has changed the landscape of education. It is important to keep up with the current trends of technology to attract the younger generations to learn effectively and stay on top of the trends of the day.

The online education was already popular in the education industry globally since few years back but it mainly among working adult students. Majority of the students still prefer to attend conventional classes. According to a study by Paechter \& Maier (2010), Austrian students are still preferred face-to-face learning to interact and learn effectively. The Covid-19 pandemic had forced the governments around the world to prioritize the online learning. This study would like to look into the perceptions and readiness among lecturer on online distance learning. Students perceived online distance learning (ODL) as interaction between students and lecturers via online or by using technology. Less than half of the students stated that ODL was challenging and difficult. Majority of students managed to adapt with the new norm where the teaching and learning processes were held fully via ODL. Students may need more training to be well-prepared in the implementation of ODL and at the same time, they would also need to accept the changes that happened in the education system especially at tertiary level.

\section{Online Distance Learning During Covid-19}

The blended learning model has been proposed to implement up to $70 \%$ of programmes in all higher learning institutions by the Malaysian Ministry of Education (Malaysian Education Blueprint 2015-2025 (Higher Education): E-16). It can be seen that the younger generations are easily to adapt this style of learning because they are still able to have face-to-face learning. The lecturer's readiness on the other hand is still unknown whether they are able to adapt with the new norm that needed them to carry out the lesson, marking and evaluating fully through online. The issues arise whether the facilities provided are available to support the online teaching and learning session and the perception of online distance learning among the lecturers in higher learning institutions.

The advancement of technology not only affects the human lifestyles, but it also has changed the landscape of education ( $\mathrm{Ni}$ She at al., 2019) Blended learning that combines the traditional classes with online teaching is one of the efforts by the educators to keep up with the current trends of technology to attract the younger generations. Online education was already popular in the education industry globally since few years back but it mainly among working adult students who were unable to attend classes like full-time student (Moore, Dickson-Deane \& Galyen, 2011). Majority of the students are still prefer to attend conventional classes. According 
to a study by Paechter \& Maier (2010), they found that Austrian students are still preferred faceto-face learning to interact and learn effectively.

Orton-Johnson (2009) recorded a similar result from the students in the UK, they preferred to use physical text materials rather than online materials during learning. However, the Covid-19 pandemic had forced the governments around the world to prioritize the online learning and closed down all the learning institutions. Thus, this study would like to look into the perceptions and readiness among lecturer on online distance learning.

Prior to the COVID-19 pandemic, e-learning increased by around 15.4 percent annually in educational institutions around the world, without uncertainties or burden on those institutions or students. The situation has however, changed drastically as this study was performed during COVID-19As a result of global restriction initiatives to limit the dissemination of COVID-19, educational institutions have begun to deliver several of their online resources, including lecturers and different examinations through several channels, to more than $60 \%$ of students worldwide. According to reports released by the World Health Organisation (WHO), COVID-19 has been reported in over 216 countries and there are areas with millions of confirmed cases.

Several countries have taken precautionary measures to deter future expected waves, including the lockdown of schools and universities and the adaptation of the coronavirus into a complete E-learning mode. This action was in reaction to the WHO's strongly advised social distance rules to avoid the spread of COVID-19. In the middle of the spring semester, which was unplanned for both teachers and students, this lockdown began.

Many research, however have previously analysed the essential success factors (CSFs) in the education field from the viewpoints of both the teacher and the students for potential progress in the e-learning environment. In order to improve a project goal, companies should evaluate the most valuable CSFs that should be accomplished. These studies have so far analysed e-learning CSFs at normal times. Yet, for several reasons, the CSFs during the COVID-19 pandemic are predicted to be different from the CSFs during normal times.

First, the transition to E-learning was unplanned for all educational institutions during COVID-19. Not all institutions had the ability to transition smoothly and not all of them had previously implemented e-learning, unlike institutions that already had e-leaning and designed and invested in the e-learning process.

Secondly, the mechanism during COVID-19 is influenced by several factors other than educational ones, such as political and health factors, making it an unusual event. For example, if they don't have a decent internet connection at home, students can visit the library at regular hours, attend tutoring sessions, and even go to places with a good Internet connection speed, unlike when students were in curfew circumstances during COVID-19. 
Thirdly, the course content of the classes taught by E-learning pre-COVID-19 was well-prepared, unlike during COVID-19 where courses were not supposed to be taught by e-leaning.

The list could continue, not only for CSFs, but for approaches to the e-learning framework as well. During the pandemic, these are just some of the key variations worth reviewing. In this paper, from the perspective of e-learning managers in different educational institutions, we address the critical success factors using multi-criteria decision-making approaches to ensure the consistency of educational goals and the prosperity of students in their education while following the guidelines of the World Health Organization (WHO for social distancing. This provides the viewpoint of administrators of e-learning, which helps us to consider the best practises that could push educational institutions to turn to e-learning during unpredictable crises. This will benefit policymakers in educational institutions, by strengthening the most important reasons to plan for to properly conduct the educational process during a crisis.

\section{Online Distance Learning and Perceptions}

Online learning can be traced back to mid-1990s has been so widespread that many institutions are offering online courses. As quoted in Kenziq (2015), Seaman and Allen (2013) estimated that over 85 percent of higher education institutions currently offer online classes, with over 62 percent offering full online academic programmes. Today, more institutions are offering online learning to learners. As we are geared towards $5 \mathrm{G}$ technology, the growth of online learning is seen to be more rapid with the emergence of high-speed internet (Vivolo, 2016). It can be seen that the landscape of online learning is more dynamic and widespread. Online learning is referred to in various terms such as "distance education", "e-learning", "blended learning", "computerbased learning", "virtual learning", "cyber learning", "tele education". It is used interchangeably to refer to online learning (Sun \& Chen, 2016).

There are many perceptions and response to online learning. Some researchers suggest that online learning is beneficial to students. Meanwhile, there are other researches that suggest online learning might hamper students' achievement. This is because too many factors and variables that contribute to successful online learning. Online learning can offer a diverse learning atmosphere, according to Clark and Scott (2008), and it is helpful to introvert learners as their voices are best heard in the online learning environment compared to conventional face-to-face classrooms that are typically dominated by more articulate and extrovert students. It can be seen that at some point, there is bright side of online learning.

Moreover, other research suggested that the outcome of online learning may vary depending on individually. Sansone et al (2011) mentions that individual aptness in the technology influences the participation in online learning. Individual interest in computers or technology aptness has an influence in activeness of online lesson (Sansone et al, 2011) as participation in online lesson is considered as key factor in successful learning (Clark and Scott, 2008)

However, there are also negative effects of online learning. Based on a research conducted on fifth-grade students of an elementary school in Taiwan, the formative-assessment learning 
strategy for mobile learning had an unfavourable effect on students' achievement compared to traditional approach (Chu, 2014). The reason of this unfavourable effect was due to high cognitive load, which is the overloading working memory of the students as in mobile learning, students were required to find learning materials in both real world and digital world environment in limited time frame.

It can be seen that there are various responses and perceptions of online learning. Some researchers suggest that online learning is beneficial and some researchers point out that there are negative sides of online learning. Moreover, there are factors that affect online learning successfulness. However, with the emergence of technology, online learning, will nevertheless, will be more widespread and normalize in the education industry (Aras Bozkurt, 2019).

\section{Online Distance Learning at Tertiary Level}

E-learning is one of the earliest form of online learning, it was first designed for the young working adult who were unable to attend physical classes like full-time students (Moore, Dickson-Deane \& Galyen, 2011). E-learning is a web-based education tools that uses internet and digital technology in the lesson that enable the students to learn from anywhere at any time (Al-Busaidi, 2013). The teachers are able to deliver the lesson online and share their materials in various forms such as videos, pictures, slideshows, word documents, and PDF. Through e-learning, the teachers also can monitor student's enrollment, achievement, progress and marks (Ahmad NB et al., 2015). Today, the online learning has catered all types of students from full-time, part-time and distance learner in higher learning institutions (Azhari \& Ming, 2015).

In the same report, Azhari \& Ming (2015) revealed when Malaysia's higher learning institutions started using e-learning in year 2000, the challenges at the time were the shortage of skilled lecturers, equipment and facilities, the willingness of students and the reluctance of students to accept e-learning and e-learning programmes or known as the Learning Management System (LMS). According to Pellas \& Kazanidis (2015), LMS provides tools for communication between lecturers and students, course materials, content development, and administrative tools. Massive Open Online Courses (MOOCs) were launched in 2012 to transform the higher education environment and have been used by universities and private learning institutions worldwide (Margaryan et al, 2015). MOOCs is a free web-based distance learning system that is more interactive and dynamic tools. It has been planned for the involvement of a significant number of students with testing and accreditation, requiring them to be more involved in their learning.

\section{Educator Readiness to Online Distance Learning}

Covid-19 is considered as a pandemic because of the spread of SARS-CoV 2 that infects the respiratory tract. Starting in early December 2019, the rapid spread of this disease was found among the residents of Wuhan City, Hubei Province, China. To date, according to WHO Coronavirus Disease Dashboard (2020), as of 24th June 2020, there are 9129146 confirmed cases worldwide with 473797 number of deaths reported. In Malaysia, the number of cases show significant decline due to effective measures taken by the government. 
The deadly virus of Covid-19 has changed the landscape of learning worldwide. Education institutions worldwide are closed and educators are required to teach remotely online. Malaysia Education Ministry had instructed all education institutions to be closed starting from March 18. Moreover, Malaysia Prime Minister also advised educators to make online teaching the way forward by utilizing online application like Classroom, cikgooTUBE and Zoom (Bernama, 2020).

The abrupt shift from traditional face to face learning to online posed some challenges to educators. Many educators are still overwhelmed with the transition of physical class to online learning. There are many aspects of online teaching that posed difficulty to educators as the aspects that have to be taken in online teaching is different compared to traditional teaching. Moreover, online teaching requires more work to educators. As mentioned in Ibanez and Scott (2008), online learning is not mere curriculum conversion and effective online learning cannot be done by simply converting existing face-to-face course. Bawane and Spector (2009) mentioned that various roles and skills are required to ensure an effective online learning as online learning require more flexible approach. It can be seen, teaching online requires educators to have more competencies skills compared to traditional teaching.

Furthermore, there are other aspect of readiness that needs to be highlighted in online teaching. The most obvious aspect that is always seen important is the technical ability to conduct online learning class. However, in term of technical aptness, Clark-Ibanez and Scott (2008) mentioned that there is no need for advanced technical knowledge for a successful online learning. Instead, they mentioned that educators need new pedagogy to ensure student engagement and critical thinking in the class. Clark and Scott (2008) believed that learning happens through interaction and active participation. Thus, the approach that works in online learning is the constructivist approach that instructor facilitates student learning. It can be seen, a more complex set of skills that includes new pedagogy knowledge is required to ensure effective online learning.

Moreover, years of traditional teaching experience cannot be translated to online teaching. This is due to the different aspect of online teaching compared to traditional teaching. According to Hung (2016) teaching experiences has no influence on teacher's communication self-efficacy. This is because research done shows that teachers with lesser teaching experiences exhibit higher teacher's communication self-efficacy.

\section{Research Gap.}

This research attempts to clarify the understanding of learner readiness during the Covid-19 outbreak. The research shows the desires of students for e-learning, as it allows them a great deal of opportunity to communicate with their teachers, fellow students and interact with their study materials in the convenience and versatility of space and time. Quick access to online services has been reported as one of the key factors for students to opt for e-learning. The study reveals that e-learning technology provides easy access to knowledge that adds to the optimistic attitude of students towards it. This result is focused on the utility, self-efficiency, ease of use and student activity of e-learning. The research demonstrates the usefulness of e-learning, such 
as ease of study from any geographical area that is not available in the case of traditional faceto-face learning.

The research further highlights the related experience of learning through physical classroom instruction as students see e-learning as comparable to face-to-face learning. This research study shows that, in the recent past, e-learning has gained tremendous prominence in India as students are found to be susceptible to online learning platforms to communicate with each other and with educators as well. In comparison, in the absence of face-to-face engagement, visual media has also been well received by students for learning purposes. The required steps to enhance the quality of e-learning should therefore be implemented to help students learn better during the Covid-19 pandemic process.

The literature review indicates that several studies are undertaken to classify student expectations and behaviors towards e-learning, and studies relevant to student perceptions of elearning at the time of the COVID-19 pandemic are found to be rare and far between.

\section{Research Objective}

- To identify students' perceptions on the implementation of Online Distance Learning.

- To determine student's readiness on the implementation of Online Distance Learning.

\section{Discussion and Recommendation}

This study is to understand the student's perception and readiness on online distance learning. The study aims to add to the growing body of knowledge that has looked at many different variables that may affect teacher and students performance by looking at yet another variable that is important to consider. Students perceived online distance learning (ODL) as interaction between students and lecturers via online or by using technology. Other than that, less than half of the students stated that ODL was challenging and difficult. However, majority of the students managed to adapt with the new norm where the teaching and learning processes were held fully via ODL.

Furthermore, they received positive support from the university and faculty in helping them to be prepared in the implementation of ODL and they also mentioned that they preferred to have a combination of face-to-face learning together with ODL. Based on these results, it can be concluded that students have positive responds towards ODL and majority number of students are ready to follow the university demands in using ODL in order to ensure that the objectives of teaching and learning processes can be achieved in the future.

Besides, in planning the lesson, lecturers should consider students' needs and ability in receiving the lesson, so that, it would be delivered successfully. In order for the lesson and information to be delivered successfully, there are platform and applications which also known as the tools that can be used in conducting the lessons. Students should utilised suitable learning strategies so that they could understand the content of the lesson and lastly, students should prepare themselves with suitable materials and methods. This is because they also have their own 
personal goals in learning the lessons. Thus, it can be said that students may ready to continue using ODL in the future if they are well-prepared.

The education system across the world has been significantly impacted by the outbreak of COVID19; it has caused the closure of educational institutions that have negatively affected student fraternity around the globe. Owing to its infectious existence, COVID-19 called for containment and compulsory segregation, which had a tremendous effect on the intimate contact between teachers and students. In the absence of conventional classroom instruction and one-to-one engagement, computer-based learning has arisen as the closest replacement for off-line learning. In this context, it is important to analyse the understanding and preparation of students regarding the online learning framework implemented at the university level during the current pandemic of COVID-19.

The research demonstrates the students' optimistic view of e-learning and therefore the adoption of this new learning system. The value of e-learning in the time of the COVID-19 crisis has also been empirically shown. In reality, e-learning has arisen as a new medium to strengthen the learning process, where social media can help increase learning performance. The results of the report will make it possible for educational institutions and decision makers to move this online learning process to the next step in a better way.

As for recommendation, students may need more training to be well-prepared in the implementation of ODL and at the same time, they would also need to accept the changes that happened in the education system especially at tertiary level. Based on this study, the researchers would like to recommend for future research to investigate the comparison between students' and lecturers' readiness by using quantitative approach where more respondents can participate in the study.

\section{References}

Ahmad, N. B., Ishak, M. K., Alias, U. F., Mohamad, N. (2015). An Approach for E-Learning Data Analytics using SOM Clustering. Int J Adv Soft Comput Its Appl. 7(3).

Al-Busaidi, K. A. (2013). An empirical investigation linking learners' adoption of blended learning to their intention of full e-learning. Behaviour \& Information Technology, 32(11), 11681176.

Azhari, F. A., \& Ming, L. C. (2015). Review of e-learning practice at the tertiary education level in Malaysia. Indian Journal of Pharmaceutical Education and Research, 49(4), 248-257.

Bawane, J., and Spector, J. M. (2009). Prioritization of online instructor roles: implications for competency-based teacher education programs. Distance Educ. 30, 383-397. doi:10.1080/01587910903236536

Bernama. (2020). Make Online Teaching the Way Forward. The Edge. Retrieved from https://www.theedgemarkets.com/article/make-online-teaching-way-forward-pmadvises-teachers

Bozkurt, A. (2019). From Distance Education to Open and Distance Learning: A Holistic Evaluation of History, Definitions, and Theories. In S.Sisman-Ugur, \& G. Kurubacak (Eds.), Handbook 
INTERNATIONAL JOURNAL OF ACADEMIC RESEARCH IN PROGRESSIVE EDUCATION AND

DEVELOPMENT

Vol. 10, No. 1, 2021, E-ISSN: 2226-6348 @ 2021 HRMARS

of Research on Learning in the Age of Transhumanism (pp. 252-273). Hershey, PA: IGI Global.

Chu, H. (2004). Potential Negative Effects of Mobile Learning on Students' Learning Achievement and Cognitive Load-A Format Assessment Perspective. Journal of Educational Technology \& Society, 17(1)

Clark-Ibanez and Scott. (2008). Learning to Teach Online. American Sociological Association. $36(1), 34-41$.

Edudemic. (2012). 8 countries leading the way in online education. Retrieved from http://monitor.icef.com/2012/06/8-countries-leading-the-way-in-online-education/

Hung, M. L. (2016). Teacher Readiness for Online Learning: Scale Development and Teacher Perceptions. Science Direct, 94, 120-133

Kenziq, M. J. (2015). Lost in Translation: Adapting a Face-to-Face Course into an Online Learning Experience. Sage Publication. 16(5), 625-628.

Margaryan, A., Bianco, M., \& Littlejohn, A. (2015). Instructional quality of massive open online courses (MOOCs). Computers \& Education, 80, 77-83.

Maznah, R. R. H. (2004). e-Learning in Higher Education Institutions in Malaysia.

Md Abdul Haseeb, A. S. (2018). Higher Education in the Era of IR 4.0. New Straits Times. Retrieved from https://www.nst.com.my/education/2018/01/323591/highereducation-era-ir-40.

Ministry of Education Malaysia. (2015). Malaysia Education Blueprint 2015-2025, (Higher Education), Ministry of Education Malaysia

Moore, J. L., Dickson-Deane, C., \& Galyen, K. (2011). E-Learning, online learning, and distance learning environments: Are they the same? Internet Higher Education, 14(2), 129-35.

Ní Shé, C., Farrell, O., Brunton, J., Costello, E., Donlon, E., Trevaskis, S., Eccles, S. (2019). Teaching online is different: critical perspectives from the literature. Dublin: Dublin City University. doi: 10.5281/zenodo.3479402

Paechter, M., \& Maier, B. (2010). Online or face-to-face? Students' experiences and preferences in e-learning. Internet and Higher Education, 13(4), 292-297.

Pellas, N., \& Kazandis, I. (2015). On the value of second life for students' engagement in blended and online courses: A comparative study from the Higher Education in Greece. Education and Information Technologies, 20(3), 445-466.

Sansone, C., Fraughton, T., Zachary, J. L., Burtner, J., \& Heiner, C. (2011). Self-regulation of motivation when learning online: the importance of who, why and how. Educational Technology Research and Development, 59(2)

Sun, A., \& Chen, X. (2016). Online education and its Effective Practice; A research Review. Journal of Information Technology: Research, 15, 157-190

Tanis, C. J. (2020). The seven principles of online learning: Feedback from faculty and alumni on its importance for teaching and learning. Research in Learning Technology, 28.

UNESCO. (2020). Education: From disruption to recovery. Retrieved from https://en.unesco.org/covid19/educationresponse

Vivolo, J. (2016). Understanding and Combating Resistance to Online Learning. Sage Publications, Ltd., 99,4, 399-412 